\title{
Occurrence and transformation of dissolved dimethyl sulfur species in stratified seawater (western Mediterranean Sea)
}

\author{
Rafel Simó ${ }^{1, *}$, Joan O. Grimalt ${ }^{1}$, Carlos Pedrós-Alió ${ }^{2}$, Joan Albaigés ${ }^{1}$ \\ ${ }^{1}$ Department of Environmental Chemistry (C.I.D.-C.S.I.C.), Jordi Girona 18, E-08034 Barcelona, Catalonia, Spain \\ ${ }^{2}$ Institut de Ciències del Mar (C.S.I.C.), Passeig Joan de Borbó s/n, E-08039 Barcelona, Catalonia, Spain
}

\begin{abstract}
Dimethyl sulfide (DMS), dissolved dimethylsulfoniopropionate (DMSP ${ }_{\mathrm{d}}$ ) and dimethylsulfoxide (DMSO) were measured in Mediterranean seawater. In the open surface waters of late spring to early summer, DMSO (18 $\mathrm{nM})$ was the main methylated sulfur compound and dominated over DMS $(1.7 \mathrm{nM})$ by 1 order of magnitude. Conversely, DMSP ${ }_{d}$ accurred at lower concentrations (0.55 nM) than DMS. The higher abundance of DMS over DMSP ${ }_{d}$, the poor correlation between surface DMS and chlorophyll a, and microscopic examination of the algal populations suggest that DMS essentially originated from decomposition of the $\mathrm{DMSP}_{\mathrm{d}}$ generated in a late decay phase of the spring phytoplankton development. On the other hand, the vertical profile of the dissolved dimethyl sulfur species and the depth distribution of both biological DMS production and consumption rates point to the concurrence of the biogenic cycles of DMS and carbon. Thus, highest DMS production occurs near the subsurface chlorophyll maximum in coincidence with the water column layers of highest microbial heterotrophic activity. Finally, the high DMSO concentrations suggest that this species may act as a major nonvolatile dimethyl sulfur pool in these waters
\end{abstract}

KEY WORDS: Dimethyl sulfide - Dimethylsulfoniopropionate - Dimethylsulfoxide - Stratified marine systems $\cdot$ Microbial heterotrophic activity

\section{INTRODUCTION}

Dimethyl sulfide (DMS) has been identified as the most abundant volatile sulfur compound in surface seawater, where it occurs at concentrations high enough to account for the major part of the sulfur flux from the oceans to the atmosphere (Lovelock et al. 1972, Andreae 1990). The atmospheric oxidation of DMS yields submicron-size sulfate and sulfonate particles, thereby affecting the acidity of atmospheric deposition and serving as a precursor of tropospheric aerosols and cloud condensation nuclei (Charlson \& Rodhe 1982, Charlson et al. 1987). Since the suggestion that DMS may play a major role in global climate regulation through the latter mechanism (Bates et al. 1987, Charlson et al. 1987), many efforts have been devoted to the study of the biogeochemical processes that control DMS concentration in surface seawater and its emission to the atmosphere.

•E-mail: rsmqam@cid.csic.es
DMS is produced within the water column through biological mechanisms. Its most important source is the algal component dimethylsulfoniopropionate (DMSP) which is found in dissolved and, more abundantly, in particulate form. This compound is transformed into DMS by enzymatic cleavage, mostly during phytoplankton senescence and grazing by zooplankton (Dacey \& Wakeham 1986, Turner et al. 1988, Leck et al. 1990). Once released, DMS is subject to a variety of sinks in addition to air-sea exchange, including biological consumption (Kiene \& Bates 1990), photooxidation (Brimblecombe \& Shooter 1986), and adsorption onto sedimenting particles (Shooter \& Brimblecombe 1989). Recently, it has been recognized that microbial consumption dominates the marine DMS turnover far over abiotic losses (Kiene \& Bates 1990, Leck et al. 1990, Bates et al. 1994) and that atmospheric emission is just a small bleed of the biological cycle. Nevertheless, the agents of this consumption and their transformation pathways are far from being under- 
stood (Taylor \& Kiene 1989, Wakeham \& Dacey 1989, Kiene 1992).

The scarce available data on dimethylsulfoxide (DMSO) distributions in open seawaters suggest that this compound may play a significant role in the oceanic sulfur cycle since it occurs at concentrations generally higher than those of DMS and represents a major pool of dissolved dimethyl sulfur (Andreae 1980a, Lee \& Wakeham 1989, Gibson et al. 1990, Ridgeway et al. 1992, Bates et al. 1994). However, the knowledge on the relationships between DMS and DMSO occurrence in the ocean is very limited. In the present study, the first joint measurements of DMS, dissolved DMSP (DMSP $)$ ) and DMSO concentrations in Mediterranean seawater are reported. Furthermore, seawater incubation experiments were performed to estimate the depth profiles of both microbial DMS consumption and production rates. This approach provides the first comprehensive information on DMS biological cycling throughout the stratified water column.

\section{MATERIALS AND METHODS}

Sampling. Sampling was carried out during 2 cruises in the western Mediterramean Sea, one aboard the RV 'Hespérides' in the Catalan Sea (June 1 to 6 and 22 to 29,1993 ) and the other aboard the RV 'Discovery' in the central basin and top northwestern shelf (July 17 to August 2, 1993). The location of the stations is indicated in Fig. 1. Water samples from 5 to $1000 \mathrm{~m}$ depths were collected with Niskin bottles attached to a CTD (conductivity/temperature/ depth) hydrocast system. Aliquots were taken in silanized, dark glass flasks, with no headspace, and preserved at $4^{\circ} \mathrm{C}$ with $0.2 \mathrm{ml}$ of $25 \% \mathrm{HCl}$ until analysis. When possible (i.e. in the 'Hespérides' cruise, Samples 1 to 12 ) the analyses were performed immediately on board. In the 'Discovery' cruise (Samples 13 to 16 ) aliquots were $\mathrm{GF} / \mathrm{F}$ filtered, acidified and frozen at $-20^{\circ} \mathrm{C}$ in well-closed polyethylene flasks until analysis in our laboratory in Barcelona, Spain. Tests with both standards and real samples revealed that no DMSP or DMSO was lost during storage. DMS concentrations in Samples 13 to 16 have to be taken as approximate values because they have been corrected for $50 \%$ losses which occurred during frozen storage.
Analyses. Analyses of DMS were performed following a modified method based on a cryo-trapping gas chromatographic technique described elsewhere (Simó et al. 1993). Subsample volumes of 25 or $50 \mathrm{ml}$ were taken with a Teflon tube attached to a glass syringe. The tube was then replaced with a filter unit holding a $2.4 \mathrm{~cm} \mathrm{GF/F} \mathrm{filter} \mathrm{(Whatman,} \mathrm{Maidstone,} \mathrm{UK)} \mathrm{con-}$ nected to a needle. With this filtration unit, the volume was injected into the purge device through a Teflonfaced septum by applying very gentle pressure. The purge device consisted of a silanized glass flask provided with a Teflon-capped side-port and a porous glass frit at the inlet of the sparging gas. Volatile sulfur compounds (VSC) were stripped by sparging the water sample with nitrogen (ultrahigh purity) at a flow rate of $150 \mathrm{ml} \mathrm{min}{ }^{-1}$ for $20 \mathrm{~min}$, and cryo-trapped at the temperature of liquid argon. A Nafion dryer (PermaPure Inc., Toms River, NJ, USA) was located between the purge flask and the cryogenic trap to avoid ice blocking in the trap loop. Once sparging was completed, the cryo-trap was connected to the gas chromatograph by means of 6 port valves. Injection was performed by quickly placing the loop in hot water. Volatiles were cryo-focused again in a second, smaller cryogenic trap before entering the column in order to avoid peak widening.

The gas chromatograph was specially designed for the field analysis of VSC (Haunold et al. 1992). It was equipped with a flame photometric detector and a $2 \mathrm{~m}$ $\times 1 / 8 "$ Teflon column filled with Carbopack BHT-100

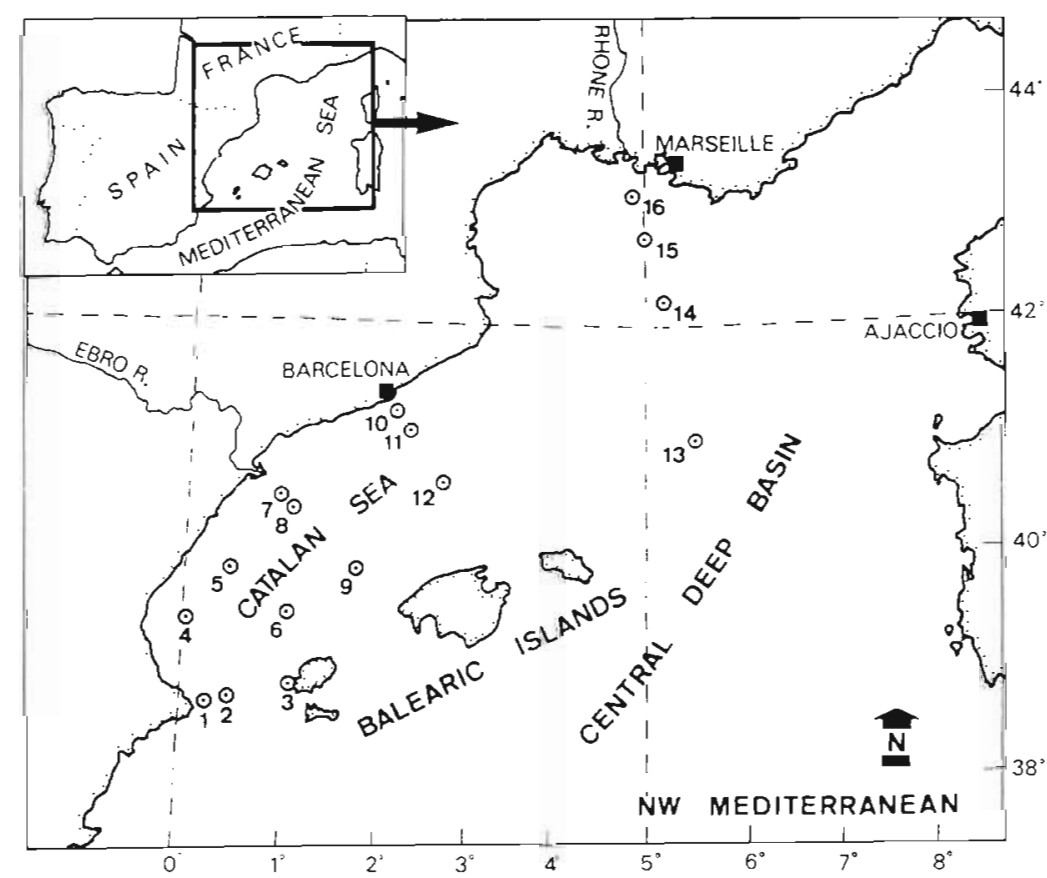

Fig. 1 Location of the sampling stations considered in this study. Numbers refer to Table 1 
(Supelco, Bellefonte, PA, USA). Base line separation of DMS from other VSC $\left(\mathrm{CS}_{2}, \mathrm{DMDS}, \mathrm{CH}_{3} \mathrm{SH}, \mathrm{COS}, \mathrm{H}_{2} \mathrm{~S}\right)$ was achieved using a temperature program from 50 to $100^{\circ} \mathrm{C}$ and a carrier gas flow rate of $20 \mathrm{ml} \mathrm{min}^{-1}$. Peak areas were recorded with a Hewlett-Packard 3393A integrator. Calibration was performed by injecting known amounts of gaseous DMS released by a permeation tube (VICI Metronics, Santa Clara, CA, USA) and diluted with nitrogen flow in a steady-temperature $(30 \pm$ $0.1^{\circ} \mathrm{C}$ ) permeation chamber. Interpolation on linear $\log$ (Peak area) - log (DMS mass) plots allowed quantification. The detection limit for $50 \mathrm{ml}$ water samples was $0.05 \mathrm{nM}$. Mean relative standard deviation for real water sample replicates was $6 \%$.

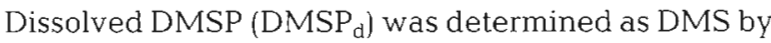
the cold alkali treatment method (Dacey \& Blough 1987. Turner et al. 1988). After volatiles were removed from filtered water by sparging, the samples were transferred to silanized dark glass bottles and brought to the brim with milliQ water. Then 100 to $200 \mathrm{mg}$ of $\mathrm{NaOH}$ were added to set the $\mathrm{pH}$ from acidic to $\sim 13$. The sample was left to react at room temperature for $6 \mathrm{~h}$, after which time all DMSP had decomposed into DMS. After neutralizing with $\mathrm{HCl}$, the newly formed DMS was stripped from the solution and measured as described above. Recoveries using this procedure, calculated with replicates of standard solutions, were always near $100 \%$. The relative standard deviation was $<10 \%$.

DMSO was determined by transformation into DMS (Andreae 1980b) in a further step. Once DMSP $d$ was eliminated via DMS formation and stripping, 1 pellet (45 mg) of $\mathrm{NaBH}_{4}$ was added to the neutralized sample in the purge flask and allowed to react for 6 to 15 min. During this reaction time the purge device was connected to the cyogenic trap for the preconcentration of the stripped volatiles. The application of a very gentle flow (max. $40 \mathrm{ml} \mathrm{min}^{-1}$ ) of the sparging gas during the first minutes after $\mathrm{NaBH}_{4}$ addition allowed borohydride to dissolve slowly and effectively react with DMSO. After the reaction time, $\mathrm{HCl}$ was added and sparging proceeded at $150 \mathrm{ml} \mathrm{min}^{-1}$ for 20 additional minutes. Bubbles of $\mathrm{H}_{2}$ and boranes evolved enough to enhance the sparging of the DMS produced, but not so much as to cause interference in DMS detection by diborane saturation of the FPD signal. Again, DMS was trapped and measured as described above. The relative standard deviation $(<20 \%)$ was calculated with replicates of standard solutions. Since DMSP was seen to be decomposed to DMS by borohydride (Andreae 1980b, R. Simó, J. Grimalt \& J. Albaigés unpubl.), analysis of DMSO must necessarily be performed after quantitative removal of DMSP. Tests with standards (DMSP.HCl: Research Plus, Inc., Bayonne, NJ, USA; DMSO: Carlo Erba, Milano, Italy) were carried out to ensure the lack of interferences between the 2 species. No interferences other than DMSP have been described in the borohydride reduction of DMSO (Andreae 1980b).

Blank controls of milliQ water treated with the series of reagents used in these procedures were performed as well. No DMS peak was observed after alkali treatment. In addition to the borane-related peak, a small DMS signal (equivalent to a concentration lower than $0.5 \mathrm{nM}$ ) sometimes appeared after addition of $\mathrm{NaBH}_{4}$ to blanks. More analytical details will be given elsewhere (Simó et al. unpubl.).

Incubation experiments. Incubation experiments were carried out on board with water samples from Stn 12. Freshly collected aliquots from depths 5, 30, 50 and $80 \mathrm{~m}$ were incubated in $60 \mathrm{ml}$, silanized, dark glass bottles capped with Teflon septa and completely filled. Before use, incubation flasks were rinsed with acid (HCl) diluted in milliQ water and with sample water. DMS concentrations were measured several times during the experiment. Each sample consisted of a series of 4 bottles, each bottle providing 1 subsample to be analyzed. This system allowed avoidance of possible DMS losses into the headspace created by water withdrawing from a single flask. Incubations were performed within $3^{\circ} \mathrm{C}$ of the in situ temperature, as well as in the dark to prevent photochemical destruction of DMS. Inhibited incubation series were prepared by addition of chloroform to a final concentration of $500 \mu \mathrm{M}$.

Measurement of bacterial abundance and heterotrophic activity. Chlorophyll a (chl a) was measured by fluorometry in acetone extracts (Yentsch \& Menzel 1963). Bacterial abundance was determined by epifluorescence microscopy of DAPI stained preparations (Porter \& Feig 1980). Bacterial heterotrophic activity was determined from the incorporation of tritiated leucine into macromolecules (Kirchman 1993). Two $20 \mathrm{ml}$ samples and a formaldehyde-killed control from each depth were incubated in scintillation vials with $0.14 \mu \mathrm{Ci} \mathrm{ml} \mathrm{m}^{-1}$ of tritiated leucine for $2 \mathrm{~h}$ in the dark (final leucine concentration $40 \mathrm{nM}$ ). Incubations were stopped with formaldehyde. Samples were filtered through $0.45 \mu \mathrm{m}$ pore size membrane filters, extracted with ice cold TCA and rinsed with cold ethanol. Filters were placed in scintillation vials with $1 \mathrm{ml}$ ethyl acetate to dissolve the filters and scintillation cocktail added. Radioactivity was determined in a scintillation counter.

\section{RESULTS}

\section{DMS, DMSP $\mathrm{d}_{\mathrm{d}}$ and DMSO concentrations in surface seawaters}

Surface concentrations of DMS, DMSP, DMSO and chl a measured during the 2 cruises in the western Mediterranean are shown in Table 1 . These data cor- 
Table 1. Dimethyl sulfide (DMS), dimethylsulfoxide (DMSO), dissolved dimethylsulfoniopropionate (DMSP (Dnd $_{\text {chl }}$ a in surface waters ( 1 to $5 \mathrm{~m}$ ) from the northwestern Mediterranean Sea. nd: not determined

\begin{tabular}{|c|c|c|c|c|c|c|c|c|}
\hline $\begin{array}{c}\text { Sample } \\
\text { ref. }\end{array}$ & $\begin{array}{c}\text { Cruise } \\
\text { ref. }\end{array}$ & Location & $\begin{array}{l}\text { DMS } \\
\text { (nM) }\end{array}$ & $\begin{array}{c}\text { DMSO } \\
(n M)\end{array}$ & $\begin{array}{c}\mathrm{DMSP}_{\mathrm{d}} \\
(\mathrm{nM})\end{array}$ & $\begin{array}{c}C h I^{a} \\
\left(\mu \mathrm{H} \mathrm{l}^{-1}\right)\end{array}$ & Date & $\begin{array}{l}\text { Local } \\
\text { time }\end{array}$ \\
\hline 1 & FNT1 & $38^{\circ} 47.84^{\prime} \mathrm{N}, 0^{\circ} 19.62^{\prime} \mathrm{E}$ & 1.8 & 32.5 & 0.95 & 0.39 & $1 \mathrm{Jun}$ & $22: 00$ \\
\hline 2 & FNT3 & $38^{\circ} 50.20^{\prime} \mathrm{N}, 0^{\circ} 44.20^{\prime} \mathrm{E}$ & 1.5 & 23 & 0.20 & 0.20 & 2 Jun & $0: 15$ \\
\hline 3 & FNT5 & $38^{\circ} 53.75^{\prime} \mathrm{N}, 1^{\circ} 9.57^{\prime} \mathrm{E}$ & 1.3 & 11 & nd & 0.09 & 2 Jun & $3: 00$ \\
\hline 4 & FNT9 & $39^{\circ} 21.72^{\prime} \mathrm{N}, 0^{\circ} 1.72^{\prime} \mathrm{E}$ & 0.7 & 29.5 & 0.07 & 0.17 & 2 Jun & $11: 00$ \\
\hline 5 & FNT22 & $39^{\circ} 44.87^{\prime} \mathrm{N}, 0^{\circ} 32.37^{\prime} \mathrm{E}$ & 0.9 & 23 & 0.84 & 0.13 & 3 Jun & $13: 15$ \\
\hline 6 & FNT26 & $39^{\circ} 31.08^{\prime} \mathrm{N}, 0^{\circ} 58.45^{\prime} \mathrm{E}$ & 3.3 & 24 & 0.74 & 0.11 & 3 Jun & $13: 15$ \\
\hline 7 & FNT43 & $40^{\circ} 37.44^{\prime} \mathrm{N}, 1^{\circ} 0.16^{\prime} \mathrm{E}$ & 19 & 29 & 0.89 & 0.35 & 4 Jun & $22: 15$ \\
\hline 8 & FNT44 & $40^{\circ} 29.95^{\prime} \mathrm{N}, 1^{\circ} 9.12^{\prime} \mathrm{E}$ & 2.3 & 23 & nd & 0.14 & 5 Jun & $0: 30$ \\
\hline 9 & FNT49 & $40^{\circ} 1.75^{\prime} \mathrm{N}, 1^{\circ} 41.60^{\prime} \mathrm{E}$ & 1.4 & 21 & 0.06 & 0.09 & $5 \mathrm{Jun}$ & $8: 1.5$ \\
\hline 10 & FNT68 & $41^{\circ} 15.30^{\prime} \mathrm{N}, 2^{\circ} 16.03^{\prime} \mathrm{E}$ & 15 & 62 & nd & 0.22 & $6 \mathrm{Jun}$ & $13: 00$ \\
\hline 11 & FNT135 & $41^{\circ} 6.53^{\prime} \mathrm{N}, 2^{\circ} 23.17^{\prime} \mathrm{E}$ & 2.0 & 10 & 0.93 & 0.14 & 23 Jun & $11: 00$ \\
\hline 12 & FNT272 & $40^{\circ} 39.33^{\prime} \mathrm{N}, 2^{\circ} 45.62^{\prime} \mathrm{E}$ & 2.3 & 31 & 0.35 & 0.11 & 24 Jun & $11: 00$ \\
\hline 13 & MA1 & $40^{\circ} 57.56^{\prime} \mathrm{N}, 6^{\circ} 2.08^{\prime} \mathrm{E}$ & 0.5 & 5.6 & 0.53 & 0.17 & $18 \mathrm{Jul}$ & $8: 00$ \\
\hline 14 & $\mathrm{MA} 3$ & $42^{\circ} 9.86^{\prime} \mathrm{N}, 5^{\circ} 23.35^{\prime} \mathrm{E}$ & 0.9 & 12 & 0.91 & 0.23 & 24 Jul & $11: 00$ \\
\hline 1.5 & MA5 & $42^{\circ} 42.28^{\prime} \mathrm{N}, 5^{\circ} 5.23^{\prime} \mathrm{E}$ & 3.3 & 4.05 & 0.51 & 0.18 & $26 \mathrm{Jul}$ & $12: 00$ \\
\hline 16 & MA7 & $43^{\circ} 5.24^{\prime} \mathrm{N}, 4^{\circ} 56.44^{\prime} \mathrm{E}$ & 13 & 6.2 & 0.13 & 0.73 & $28 \mathrm{Jul}$ & $8: 00$ \\
\hline
\end{tabular}

respond to a group of representative cases selected among a larger data set constituting the first DMS and DMSP $_{d}$ measurements ever reported in such a broad area of the Mediterranean Sea (Simó et al. unpubl.). Previous determinations of dimethylated sulfur in this region were mostly restricted to nearby coastal areas in the Ligurian Sea (Nguyen et al. 1978, Belviso et al. 1993, Boniforti et al. 1993)

DMS concentrations were locally highest at coastal sites where elevated inputs of continental-derived nutrients and organic matter occur, i.e. off the Ebro and the Rhone pro-deltas, and on the shelf close to the city of Barcelona (Stns 7, 16 and 10, respectively). These DMS maxima were generally coincident with local maxima of chl $a$, but at Stn 1 the high chl a levels were not in correspondence with high DMS concentration. Despite the general coincidence between DMS and chl a maxima, no significant correlation between these 2 compounds was obtained for the whole set of samples. Temperatures ranged between 17 and $23^{\circ} \mathrm{C}$.

The average DMS concentration in the overall open sea area (Stns 1 to $6,8,9,11$ to 15 and additional data not shown) was $1.7 \mathrm{nM}$, a value rather close to the global mean predicted for temperate seas (2.1 nM Andreae 1990). In contrast, the mean concentration of DMSP $_{d}$ was very low (0.55 nM) and resulted in a DMSP $_{d} /$ DMS average ratio of 0.4 , which is far below ratios reported previously for other marine regions $(1.8$ to 5; Turner et al. 1988, Gibson et al. 1990, Malin et al. 1993). Moreover, no significant correlation between these 2 species was obtained.

Table 1 also displays the results of the first measurements of DMSO ever performed in the Mediterranean Sea. Surface DMSO concentrations were well above those of DMS and DMSP ${ }_{d}$, reaching values as high as $62 \mathrm{nM}$ in shelf waters off Barcelona. Open sea measurements averaged $18 \mathrm{nM}$ and resulted in a mean DMSO/DMS ratio of 14 , being higher than 10 at 8 of 13 stations. Low ratios (0.5 to 4$)$ were observed at continental-influenced locations (Stns 7,10 and 16). Hence, in early summer DMSO was the main dissolved methylated sulfur compound in Mediterranean surface waters. As far as we are aware, only a few studies have reported DMSO occurrence in seawaters (Andreae 1980a, Lee \& Wakeham 1989, Gibson et al. 1990, Ridgeway et al. 1992, Bates et al. 1994), and one of them (Andreae 1980a) needs reexamination since the analytical method did not fully distinguish between DMSO and DMSP (Andreae 1980b). In all these previous reports DMSO concentrations were equal to, or greater than, those of DMS.

\section{Depth profiles}

Depth profiles of DMS, DMSP . DMSO, chl a, bacterial abundance and temperature at Stns 11 (continental slope, water column $1100 \mathrm{~m}$ depth) and 12 (deep basin, water column $2000 \mathrm{~m}$ depth) are shown in Fig 2. Vertical profiles of temperature and chl a showed the typical summer stratification in the western Mediterranean, with a deep chlorophyll maximum (DCM). Bacteria showed a small maximum of abundance slightly above the DCM (Fig. 2). Vertical profiles of leucine incorporation also showed maximal diurnal activity at this bacterial maximum (see Fig. 4). Consistent with previous studies (Andreae 1990), DMS and $\mathrm{DMSP}_{\mathrm{d}}$ were mostly restricted to the euphotic 
Fig 2. Depth profiles of DMS, DMSO, DMSP , chl a, bacterial abundance and temperature at Stns 11 (top) and 12 fbottom; location in Table 1)
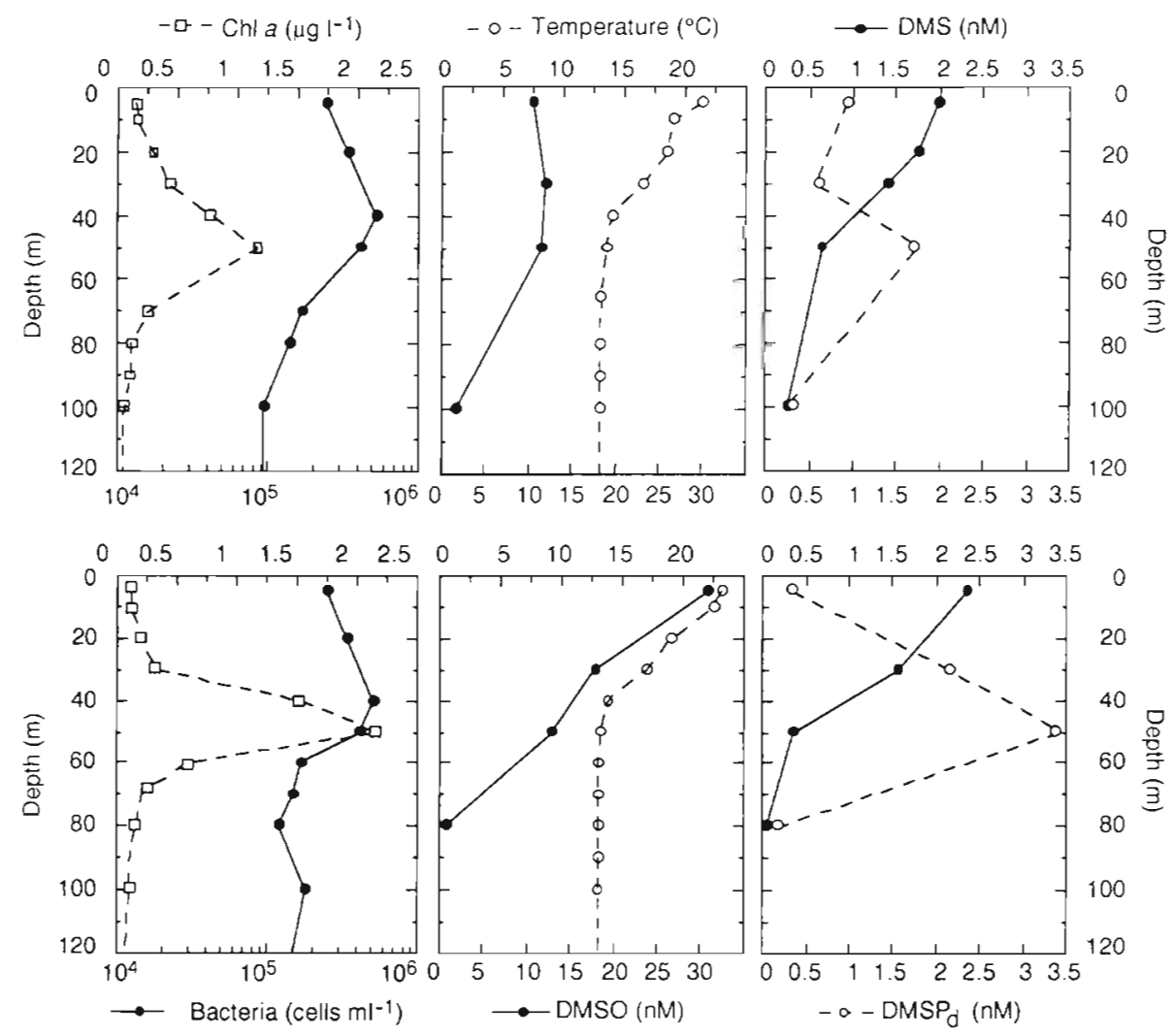

zone. Maximal DMS concentrations occurred at the surface, while DMSP ${ }_{d}$ exhibited a distribution that paralleled that of chl $a$, with a deep maximum just below the thermocline. DMSO was also confined to the photic layer, and its depth profile essentially followed that of DMS, although at concentrations 10 times higher.

\section{Incubation experiments}

The results of the incubations of samples from Stn 12 are shown in Fig. 3, where DMS time courses are plotted for several depths with and without addition of chloroform. In all cases, a slight to steep increase in DMS concentration was observed during the first $14 \mathrm{~h}$. Probably, this increase was the net result of DMS formation due to the enzymatic cleavage of the DMSP excreted by algal cells and microbial DMS consumption. Chloroform was added as an inhibitor of C1 metabolism. This compound blocks DMS consumption but, in principle, does not affect DMS production through DMSP breakdown (Kiene 1990, Kiene \& Bates 1990, Kiene \& Service 1991, Kiene 1992). Thus, the subtraction of DMS accumulation rates resulting from the inhibited and noninhibited incubations gives an estimation of the microbial consumption rate (Kiene \&
Fig. 3. Time course of DMS concentrations in inhibited (INH) and noninhibited ( $\mathrm{N}$ INH) aliquots of water from several depths at Stn 12

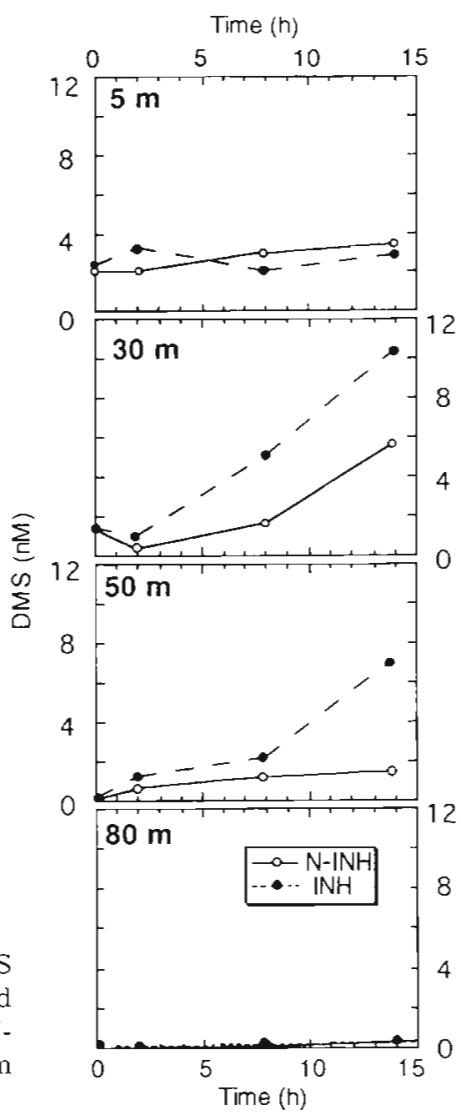




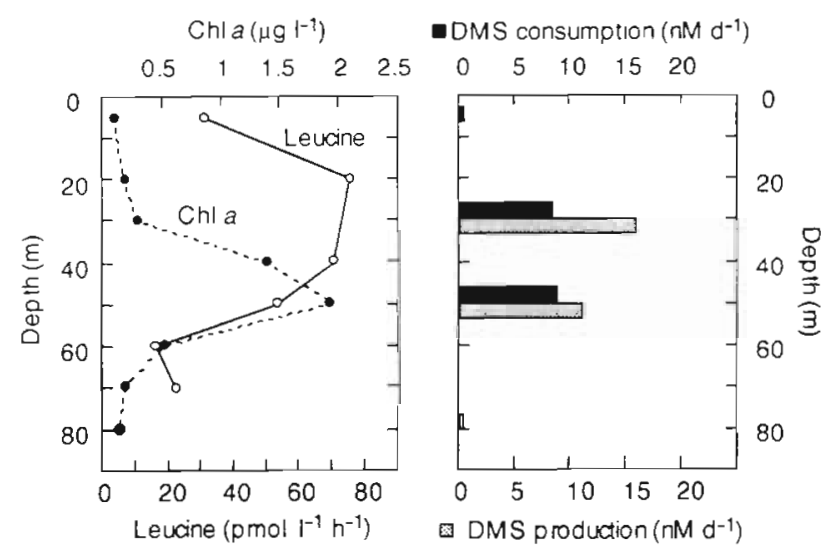

Fig. 4. Heterotrophic bacterial activity (leucine, left) and microbial DMS consumption and production rates (right) in water from several depths at $\operatorname{Stn} 12$

Bates 1990). Values around 8 to $9 \mathrm{nM} \mathrm{d}^{-1}$ were obtained at 30 and $50 \mathrm{~m}$ depth, whereas no significant consumption was measured at 80 and $5 \mathrm{~m}$ (Fig. 4). These values are on the same order as the few others reported in the literature. Kiene \& Bates (1990) estimated removal rates between 1.1 and $5.1 \mathrm{nM} \mathrm{d}^{-1}$ (with 1 outlier of $18.0 \mathrm{nM} \mathrm{d}^{-1}$ ) in surface waters $(5 \mathrm{~m}$ ) of the eastern Pacific. Kiene (1992) estimated rates between 0.1 and $3 \mathrm{nM} \mathrm{d}^{-1}$ in the same area and in the Sargasso Sea. Consistent with the results reported by Kiene, DMS consumption rates in Mediterranean seawater varied with depth, being low below the mixed layer $(80 \mathrm{~m})$. Maximal rates were observed at depths around the deep chl $a$ and $\mathrm{DMSP}_{\mathrm{d}}$ maxima (30 to $50 \mathrm{~m}$ ).

These data allow calculation of the DMS turnover times by dividing concentrations by consumption rates. In Stn 12, turnover times at 30 and $50 \mathrm{~m}$ were 5 and $1 \mathrm{~h}$, respectively. Although these values are lower limit estimates (see below), they are very short, indicating that the biological community near the DCM was very active in consuming DMS.

The DMS accumulation rate in the inhibited sample ( $\mathrm{CHCl}_{3}$ amendment) may be taken as an estimate of DMS production (Bates et al. 1994). Highest production rates were observed at 30 to $50 \mathrm{~m}$ (Fig. 4), that is, at the depths of highest removal rates.

Recently it has been shown that $\mathrm{CHCl}_{3}$ amendment as an inhibition technique may, in some cases, alter DMSP pools, promoting DMSP ${ }_{d}$ release from particulate DMSP ( $\left.\mathrm{DMSP}_{\mathrm{p}}\right)$, and hence it may stimulate DMS formation (Wolfe \& Kiene 1993). The $\mathrm{CHCl}_{3}$ concentration we chose for inhibition $(500 \mu \mathrm{M})$ was that reported to exhibit the maximal efficiency with the minimal DMSP excretion effect. However, the rates of both DMS production and microbial consumption shown in Fig 4 could have been overestimated and should be taken as upper values. In any case, in Mediterranean summer stratified waters, DMS production and consumption processes were concurrent in a narrow layer of the water column, around the depth of and slightly above the DCM.

The depth distribution of daytime bacterial heterotrophic activity at Stn 12 (Fig. 4) exhibited a pattern similar to those of DMS production and consumption rates. The maximum of activity found below the surface, at the depth of and above the DCM, has also been observed at other stations, being a common feature of these marine waters. This maximal activity decreased during the night to levels found in surface waters (data not shown).

\section{DISCUSSION}

\section{DMS versus DMSP $_{d}$}

The predominance of DMS among volatile sulfur compounds in western Mediterranean waters is in agreement with observations in other marine areas (Andreae 1990). Unlike in previous studies, DMS concentrations were even higher than those of its main precursor, DMSP $_{d}$. However, DMSP $p$ was not measured. In any case, these low concentration values are specific to the sampling period considered in this study. In other periods of the year, e.g. April, the values found in the same area are 1 order of magnitude higher (Simó et al. unpubl.). The higher abundance of DMS over DMSP ${ }_{d}$, together with the lack of correlation between DMS and chl $a$, may be indicative of a late stage in the decay of the spring algal bloom typical of the area. In this respect, lags between chl $a$ and DMS concentrations observed in other marine systems (Baltic Sea) have indicated that maximal DMS concentrations are found after maximal biomass development (Leck et al. 1990). This chl a/DMS decoupling, and the assumed criterion that $\mathrm{DMSP}_{\mathrm{d}}$ breakdown is probably faster than DMS losses (Kiene \& Service 1991), suggest that high DMS concentrations may occur when chl a and/or DMSP $\mathrm{d}_{\mathrm{d}}$ are depleted at the late decay phase of a bloom. Microscopic examination of samples from Stns 1 to 12 revealed moderate numbers of unhealthy, mixed algal cells (R. Margalef pers. comm.), hence confirming the decaying state of the phytoplanktonic community.

\section{Biogenic DMS cycling}

The discovery of the extent of microbial DMS consumption in the marine environment was of great biogeochemical significance (Kiene \& Bates 1990). Our 
results from the western Mediterranean indicate that this consumption is spatially coupled with DMS production (Fig. 4), thus constituting a tight biological cycling that probably represents the main factor in controlling the DMS concentration in seawater Moreover, comparison of Figs, $2 \& 4$ shows that, in summer stratified waters, highest production rates of DMS may not necessarily be found at the depths of highest concentrations. Both maximal consumption and production rates were found in subsurface waters, in the low thermocline, whereas maximal concentrations occurred at the surface. On the other hand, DMSP was mostly accumulated in the DCM zone and above, where it yielded DMS, and from where it might be exported to the mixed layer.

Bacterial heterotrophic activity, as indicated by leucine incorporation (Fig. 4), was also highest at subsurface depths where measured DMS turnover (production and consumption) was highest. The involvement of bacteria in both DMS production from DMSP $_{\mathrm{d}}$ and DMS consumption has been demonstrated (Kiene 1990, 1992), suggesting that DMS and DMSP may play an important role in the marine microbial cycling of $\mathrm{C} 1$ compounds. Thus, heterotrophic bacteria would cleave DMSP to utilize acrylate making DMS available for methylotrophs, the most likely consumers (Kiene 1993). The leucine measurements of the present study are not specifically related with the activity of methylotrophic species. In this respect, it has to be mentioned that the DMS-oxidizing strains isolated by Hansen et al. (1993) were not specialized in the use of C1 substrates.

On the other hand, the water column sections with highest DMS biogenic cycling were also concurrent with the DCM section (and that situated just above this layer), pointing to the involvement of subsurface plankton in the DMS cycling. Different plankton communities are found at the surface and in the DCM layer (Estrada et al. 1993) and most of the carbon flow through microorganisms occurs at the DCM and not at the surface (Vaqué et al. 1994). Thus, in summer stratified, oligotrophic waters, the biogenic DMS and carbon cycling occur in close association.

\section{DMS versus DMSO}

In view of the scarce reports of DMSO occurrence in seawater, the implication of this component in the marine cycling of methylated sulfur has been anticipated (Taylor \& Kiene 1989, Wakeham \& Dacey 1989, Malin et al. 1992, Kiene 1993, Liss et al. 1993, Bates et al. 1994) but so far there is not enough reliable information on its distribution and dynamics to assess the extent and pathways of this implication.
The depth distributions of DMSO shown in Fig. 2, typical of plankton metabolites, point either to a direct biological source for DMSO or to a photochemical transformation of some other biologically produced component. Although the occurrence of DMSO in oxic seawater was initially attributed to direct algal excretion (Andreae 1980a, Wakeham et al. 1987), more recent data suggest an origin related with photochemical and/or microbial oxidation of the DMS present in the water column (Brimblecombe \& Shooter 1986, Taylor \& Kiene 1989, Wakeham \& Dacey 1989, Malin et al. 1992, Kiene 1993).

In the presence of photosensitizers, DMS undergoes photochemical degradation in aqueous solution, involving the consumption of $1 \mathrm{~mol}$ of oxygen per $2 \mathrm{~mol}$ of DMS, consistent with the stoichiometry of DMSO formation (Brimblecombe \& Shooter 1986). High daytime insolation occurred during both cruises in the western Mediterranean. DMSO is quite resistant to photo-oxidation (Brimblecombe \& Shooter 1986) so the photochemical DMS degradation might have contributed to the high levels of DMSO observed near the surface. Nevertheless, a very preliminary experiment carried out at Stn 12, involving the concentration of microbiota by tangential filtration and subsequent DMS spiking, revealed that DMSO could be produced during early stages of DMS microbial oxidation $(R$. Simó unpubl. data).

Only part of the bacterial oxidation of DMS is expected to yield DMSO. Several of the aerobic DMSutilizing bacteria so far identified belong to the genera Hyphomicrobium and Thiobacillus, both of which give rise to $\mathrm{CO}_{2}$ and sulfate when grown on DMS (Taylor \& Kiene 1989, Kiene 1992, Hansen et al. 1993 and references therein). In estuarine waters, Wolfe \& Kiene (1993) have found that ${ }^{14} \mathrm{C}$-DMS is mostly incorporated into particles or oxidized to $\mathrm{CO}_{2}$, in contradiction with the partial conversion into dissolved material observed in a previous work (Wolfe \& Bates 1993). In the marine mixed layer, biological DMSO production is expected to proceed via monooxygenase activation in aerobic bacteria (Taylor \& Kiene 1989). Recently it has been shown that the nitrifying bacteria Nitrosomonas europaea and Nitrosococcus oceanus can convert DMS to DMSO with an ammonia monooxygenase (Juliette et al. 1993). Also worth noting is the discovery of the DMS-to-DMSO aerobic oxidation by a Pseudomonas acidovorans strain isolated from a peat biofilter (Zhang et al. 1991). Hence, the bacterial DMS transformation observed in the subsurface waters of the present study (Figs. $3 \& 4$ ) probably yielded complementary amounts of DMSO and other products, the rate of each process depending on the microbial groups present.

On the other hand, some of the above-mentioned Hyphomicrobium, Thiobacillus and Pseudomonas 
strains were also able to metabolize DMSO, the initial step of this metabolism being the reduction to DMS (Suylen et al. 1986, Taylor \& Kiene 1989, Zhang et al. 1991). DMSO reduction to DMS has also been observed in laboratory cultures of a variety of other microorganisms (Zinder \& Brock 1978), but the occurrence of this process in oxic seawater remains to be demonstrated.

In view of the high DMSO concentrations observed in the Mediterranean waters (Fig. 2, Table 1), this compound may represent, at least in some cases, a major nonvolatile pool of dimethyl sulfur possibly acting both as a sink and as a source of DMS. This mechanism is speculative. A recent study has shown that only small amounts of DMS are produced during DMSO degradation in coastal seawater (Kiene \& Gerard 1994). This observation does not discount that DMS $\rightleftharpoons$ DMSO interconversion may be significant in open sea waters. The results described in the present study should prompt researchers to investigate the agents and rates of such transformation reactions, as well as their response to changes in DMS and DMSO concentrations, in order to assess the significance of DMSO in the marine biogeochemical cycling of DMS.

Acknowledgements. We thank the scientists and crews aboard the RVs 'Hespérides' and 'Discovery', as well as their chief scientists, Profs. Miquel Alcaraz and Fauzi Mantoura, respectively. Field assistance by Joan Isidre Calderon and Jordi Dachs is acknowledged. Thanks also to Marta Estrada and Cèlia Marrasé for providing chlorophyll and CTD data and to an anonymous reviewer whose comments greatly improved the manuscript. This work was supported by the E.E.C. Projects EROS-2000 and MAS2-CT93-0063, and the Spanish Ministry of Research and Education (Projects MAR91-0359 and AMB93-0728).

\section{LITERATURE CITED}

Andreae MO (1980a) Dimethylsulfoxide in marine and freshwaters. Limnol Oceanogr 25:1054-1063

Andreae MO (1980b) Determination of trace quantities of dimethylsulfoxide in aqueous solutions. Analyt Chem 52: $150-153$

Andreae MO (1990) Ocean-atmosphere interactions in the global biogeochemical sulfur cycle. Mar Chem 30:1-29

Bates TS, Charlson RJ, Gammon RG (1987) Evidence for the climatic role of marine biogenic sulphur Nature 329 319-321

Bates TS, Kiene RP. Wolfe GV, Matral PA, Chavez FP, Buck KR, Blomquist BW, Cuhel RL (1994) The cycling of sulfur in surface seawater of the northeast Pacific. $J$ geophys Res 99:7835-7843

Belviso S, Buat-Ménard P, Putaud JP, Nguyen BC, Claustre $H$ Neveux J (1993) Size distribution of dimethylsulfoniopropionate (DMSP) in areas of the tropical northeastern Atlantic Ocean and the Mediterranean Sea. Mar Chem 44 $55-71$

Boniforti R, Emaldi P, Ferraroli R, Maspero M, Nair R, Novo A
(1993) Preliminary data on DMS concentration in seawater samples collected from the La Spezia Gulf (Ligurian Sea). In: Restelli G. Angeletti G (eds) DMS: oceans, atmosphere and climate. Kluwer, Brussels, p 163-172

Brimblecombe P, Shooter D (1986) Photo-oxidation of dimethyl sulphide in aqueous solution. Mar Chem 19:343-353

Charlson RJ, Lovelock JE, Andreae MO, Warren SG (1987) Oceanic phytoplankton, atmospheric sulphur, cloud albedo and climate. Nature 326:655-661

CharIson RJ, Rodhe H (1982) Factors controlling the acidity of rainwater. Nature 295:683-685

Dacey JWH, Blough NV (1987) Hydroxide decomposition of DMSP to form DMS. Geophys Res Lett 14:1246-1249

Dacey JWH, Wakeham SG (1986) Oceanic dimethylsulfide: production during zooplankton grazing on phytoplankton. Science 233:1314-1316

Estrada M, Marrasé C, Latasa M, Berdalet E, Delgado $M_{1}$ Riera T (1993) Variability of deep chlorophyll maximum characteristics in the Northwestern Mediterranean. Mar Ecol Prog Ser 92:289-300

Gibson JAE, Garrick RC, Burton HR, McTaggart AR (1990) Dimethylsulfide and the alga Phaeocystis pouchetii in antarctic coastal waters. Mar Biol 104:339-346

Hansen TA, Quist P, Van der Maarel MJEC, Dijkhuizen I (1993) Isolation of marine dimethylsulfide-oxidizing bacteria. In: Restelli G, Angeletti G (eds) DMS: oceans, atmosphere and climate. Kluwer, Brussels, p 37-41

Haunold W, Georgii HW, Ockelmann G (1992) Gas chromatographic analysis of atmospheric sulfur dioxide and reduced sulfur compounds. LC-GC Int 5:28-35

Juliette LY, Hyman MR, Arp DJ (1993) Inhibition of ammonia oxidation in Nitrosomonas europaea by sulfur compounds thioethers are oxidized to sulfoxides by ammonia monooxygenase. Appl environ Microbiol 59:3718-3727

Kiene RP (1990) Dimethyl sulfide production from dimethylsulfoniopropionate in coastal seawater samples and bac terial cultures. Appl environ Microbiol 56:3292-3297

Kiene RP (1992) Dynamics of dimethyl sulfide and dimethylsulfoniopropionate in oceanic water samples. Mar Chem $37: 29-52$

Kiene RP (1993) Microbial sources and sinks for methylated sulfur compounds in the marine environment. In: Murrell JC, Kelly DP (eds) Microbial growth on $C_{1}$ compounds Intercept, Andover, p 15-33

Kiene RP, Bates TS (1990) Biological removal of dimethyl sulphide from sea water. Nature 345:702-705

Kiene RP, Gerard G (1994) Determination of trace levels of dimethylsulfoxide (DMSO) in sea water and rainwater Mar Chem 47:1-12

Kiene RP. Service SK (1991) Decomposition of dissolved DMSP and DMS in estuarine waters: dependence on temperature and substrate concentration. Mar Ecol Prog Ser $76: 1-11$

Kirchman D (1993) Leucine incorporation as a measure of bıomass production by heterotrophic bacteria. In: Kemp P, Sherr BF, Sherr EB, Cole JJ (eds) Handbook of methods in aquatic microbial ecology. Lewis Publ, Boca Raton, $p$ $509-512$

Leck C, Larrson U, Bagander LE, Johansson S, Hajdu S (1990) Dimethyl sulfide in the Baltic Sea: annual variablity in relation to biological activity. J geophys Res 95:3353-3363

Lee C. Wakeham SG (1989) Organic matter in seawater: biogeochemical processes. Chem Oceanogr 9:1-51

Liss PS, Malin G, Turner SM (1993) Production of DMS by marine phytoplankton. In: Restelli $G$, Angeletti $G$ (eds) DMS: oceans, atmosphere and climate. Kluwer, Brussels, p $1-14$ 
Lovelock JE, Maggs RJ, Rasmussen RA (1972) Atmospheric dimethyl sulphide and the natural sulphur cycle. Nature 237:452-453

Malin G, Turner SM, Liss PS (1992) Sulfur the plankton/ climate connection. J Phycol 28:590-597

Malın G, Turner SM, Liss PS, Holligan P, Harbour D (1993) Dimethylsulphide and dimethylsulphoniopropionate in the northeast Atlantic during the summer coccolithophore bloom. Deep Sea Res 40:1487-1508

Nguyen BC, Gaudry A, Bonsang B, Lambert G (1978) Reevaluation of the role of dimethyl sulphide in the sulphur budget. Nature 275:637-639

porter KG, Feig IS (1980) The use of DAPI for identifying and counting aquatic microflora. Limnol Oceanogr 25:943-948

Ridgeway R, Thornton D. Bandy A (1992) Determination of trace aqueous dimethylsulfoxide concentrations by isotope dilution gas chromatography/mass spectrometry: application to rain and sea water. J atmos Chem 14:53-60

Shooter D, Brimblecombe P (1989) Dimethylsulphide oxidation in the ocean. Deep Sea Res 36:577-585

Simó R, Grimalt JO, Albaigés J (1993) Field sampling and analysis of volatile reduced sulphur compounds in air, water and wet sediments by cryogenic trapping and gas chromatography. J Chromat 655A:301-307

Suylen GMH, Stefess GC, Kuenen JG (1986) Chemolithotrophic potential of a Hyphomicrobium species, capable of growth on methylated sulphur compounds. Arch Microbiol 146:192-198

Taylor BF. Kiene RP (1989) Microbial metabolism of dimethyl sulfide. ln: Saltzman E, Cooper WJ (eds) Biogenic sulfur in the environment. Am Chem Soc, Washington, DC, p 202-221

This article was submitted to the editor
Turner SM, Malin G, Liss PS (1988) The seasonal variation of dimethyl sulfide and dimethylsulfoniopropionate concentrations in nearshore waters. Limnol Oceanogr 33:364-375

Vaqué D, Marrasé C, Guixa N (1994) The trophic dynamics of microbial communities in an oligotrophic sea. Abstracts, American Society for Limnology and Oceanography Annual Meeting. Miami, FL.

Wakeham SG, Dacey JWH (1989) Biogeochemical cycling of dimethyl sulfide in marine environments. In: Saltzman E, Cooper WJ (eds) Biogenic sulfur in the environment. Am Chem Soc, Washington, DC, p 152-166

Wakeham SG, Howes BL, Dacey JWH, Schwarzembach RP, Zeyer $J$ (1987) Biogeochemistry of dimethylsulfide in a seasonally stratified coastal salt pond. Geochim Cosmochim Acta 51:1675-1684

Wolfe GV, Bates TS (1993) Biological consumption of dimethyl sulfide (DMS) in the marine euphotic zone: results of radioisotope experiments. In: Oremland RS (ed) The biogeochemistry of global change: radiatively active trace gases. Chapman \& Hall, New York, p 691-703

Wolfe GV. Kiene RP (1993) Radioisotope and chemical inhibitor measurements of dimethyl sulfide consumption rates and kinetics in estuarine waters. Mar Ecol Prog Ser 99:261-269

Yentsch CS, Menzel DW (1963) A method for the determination of phytoplankton chlorophyll and phaeophytin by fluorescence. Deep Sea Res 10:221-231

Zhang L, Kuniyoshi I, Hirai M, Shoda M (1991) Oxidation of dimethyl sulfide by Pseudomonas acidovorans DMR-11 isolated from peat biofilter. Biotechnol Lett 13:223-228

Zinder SH, Brock TD (1978) Dimethyl sulfoxide reduction by micro-organisms. J gen Microbiol 105:335-342

Manuscript first received: August 1, 1994

Revised version accepted: May 2, 1995 